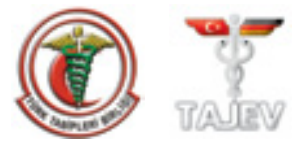

\title{
A new biological marker candidate in female reproductive system diseases: Matrix metalloproteinase with thrombospondin motifs (ADAMTS)
}

\author{
Kadir Demircan ${ }^{1}$ İsmail Cömertoğlü2, Sümeyya Akyol ${ }^{1}$, Beyza Nur Yiğitoğlu², Esma Sarıkaya ${ }^{3,4}$ \\ ${ }^{\prime}$ Department of Medical Biology, Turgut Özal University Faculty of Medicine, Ankara, Turkey \\ 2Department of Medical Genetics, Turgut Özal University Faculty of Medicine, Ankara, Turkey \\ ${ }^{3}$ Department of Reproductive Endocrinology, Zekai Tahir Burak Women's Health Education and Research Hospital, \\ Ankara, Turkey \\ ${ }^{4}$ Department of Obstetrics and Gynecology, Yildirim Beyazıt University Faculty of Medicine, Ankara, Turkey
}

\begin{abstract}
Playing a key role in the pathophysiology of many diseases, A Disintegrin-like and Metalloproteinase with Thrombospondin type-1 motif (ADAMTS) proteinases have been attracted more attention in obstetrics and gynecology. First discovered in 1997, this zinc-dependent proteinase family has 19 members today. These enzymes, which are located in the extracellular matrix (ECM), have a lot of very important functions, like matrix formation and resorption, angiogenesis, ovulation, and coagulation. In addition, in the pathogenesis of cancer, inflammation, arthritis, and connective tissue diseases, ADAMTS proteinases have crucial roles. The purpose of this review is to collect previous studies about obstetrics and gynecology that are related to ADAMTS enzymes and discuss the subject in many aspects to give an idea to the investigators who are interested in the subject. (J Turk Ger Gynecol Assoc 2014; 15: 250-5)
\end{abstract}

Key words: ADAMTS, reproductive diseases, biological marker

Received: 31 October, 2014

Accepted: 11 November, 2014

\section{Introduction}

A Disintegrin-like and Metalloproteinase with Thrombospondin type-1 motif (ADAMTS) proteinases, which are released outside the cell (soluble), have very critical roles in damage and repair of extracellular matrix (ECM) processes (remodeling) (1). The ADAMTS family, which degrades ECM structural substrates, such as collagen, aggrecan and versican, has 19 family members (2). These enzymes, which are associated with a great deal of vital physiological processes in the ECM, are inhibited by tissue inhibitors of metalloproteinases (TIMPs) $(3,4)$. Family members of this group are divided into various subgroups according to their tasks in the ECM (Figure 1).

ADAMTS1 (METH-1), which was identified for the first time in colon adenocarcinoma, is associated with inflammation (5) and shows anti-angiogenic properties with ADAMTS8 (METH-2) $(6,7)$. Especially in the physiology of ovulation, there is interest in these proteases. ADAMTS1 also takes important roles in the process of normal growth, fertility, and organogenesis (8). ADAMTS 2, 3, and 14, also known pro-collagen N-proteinases, have important roles in collagen synthesis in the ECM. Various connective tissue diseases are seen in ADAMTS2 deficiency in this group (9). ADAMTS1, $-4,-5,-8,-9,-15,-16$, and -18 degrade aggrecan, which is the one of the main components of the ECM; so, they are called as aggrecanases (1). ADAMTS1, -4 , and -5 degrade brevican and versican, other structural ECM components (10). Versican helps hyaluronan, which is the basic element of the ECM, to stabilize the matrix (11). ADAMTS5 and -6, expressed specifically in the placenta, are thought to be responsible for implantation (12). ADAMTS7 and -12 degrade Cartilage oligomeric matrix protein (COMP), which is an essential glycoprotein in cartilage matrix (13). ADAMTS10 has important roles in the development of tissues of skin and lens. In ADAMTS10 mutations, autosomal recessive Weill-Marchesani syndrome is seen (14).

Known as von Willebrand cleaving protease, ADAMTS13 has effects on coagulation and homeostasis. This protease degrades ultralarge VWF multimers that are localized in endothelial surfaces; so, it prevents thrombus formation (9). Thrombotic thrombocytopenic purpura (TTP), a serious problem during pregnancy, occurs in ADAMTS13 deficiency (15). Increased by follicle-stimulating hormone (FSH) and luteinizing hormone (LH), ADAMTS16 degrades $\alpha-2$ macroglobulin in the ECM (16). ADAMTS17 is involved in estrogen-induced apoptosis in cancer cells (16). ADAMTS9 and -20 are known 
as Gon-ADAMTS (17). ADAMTS10 and ADAMTS19, whose roles are unknown today, are called orphan ADAMTS proteases (1).

\section{ADAMTS in the Physiology of Obstetrics and Gynecology Ovarian physiology and ADAMTS}

For successful ovulation, cumulus oocyte complex (COC) formation and rupture of ovarian surface epithelium must occur properly (18). While COC formation occurs, the synthesis of basic ECM components, like versican and hyaluronic acid (HA), is increased (18).

The synthesis of proteoglycans, such as aggrecan, versican and brevican, which bind to HA, increases in the ovaries after an $\mathrm{LH}$ surge $(10,19)$. These proteoglycans are basic components of the ECM, together with HA. Versican, a substrate of ADAMTS1, -4 , and -5 , has roles in ECM remodeling, movement of cumulus cells, and maintaining the structural and functional integrity of the matrix $(10,18)$. In the peri-ovulatory period, ADAMTS1, -4 , and -5 degrade versican, resulting in the expansion of the COC $(18,19)$. For successful ovulation, this destruction must occur $(10,16,17)$.

Progesterone $(\mathrm{PG})$ and its receptor $(\mathrm{PR})$ are two genes that are activated by LH in ovaries. PG binds to receptors (PGR) on the granulosa cell resulting in increased ADAMTS1 $(8,9,20,21)$ (Figure 2). In disorders of PR, which controls expression of ADAMTS1, ovulation and fertility problems are observed. Ovulation does not occur successfully and fertility rates are reduced $(7,22)$. ADAMTS1 has critical roles in the degradation of versican, expansion of $\mathrm{COC}$ formation, ovulation and angiogenesis. In ADAMTS1-null mice, oocyte and ovarian vascular degeneration and reduction in ovarian network organization were determined $(6,9)$. Human chorionic gonadotropin (hCG), another hormone in ovulation, also stimulates secretion of ADAMTS1 in ovaries (23).

Tissue inhibitor of metalloproteinases (TIMPs), which specifically inhibit ADAMTS1, are also involved in ovulation. The balance between ADAMTS1 and TIMP3 is important for the development and regression of the corpus luteum (24).

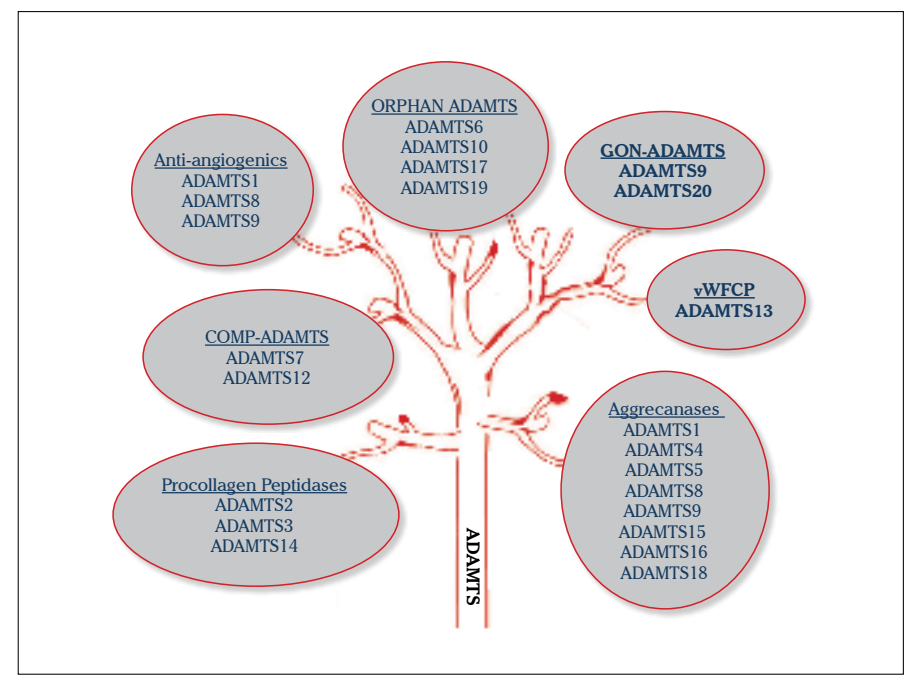

Figure 1. ADAMTS tree: Classification of ADAMTS proteinase according to their functions
Although other ADAMTS proteinases, like ADAMTS 4, -5, -9, -16, and -17 were identified in ovaries, only ADAMTS1 has been examined in detail so far (9). For these reasons, other ADAMTS proteinases are thought to have important tasks in ovulation $(2,10)$.

In a study about mice that had defective leptin hormone, the levels of gonadotropin-releasing hormone were reduced, and consequently, hypogonadism and anovulation were shown. Leptin increases ADAMTS1; so, ovulation occurs (25).

The expression of PACAP (pituitary adenylate cyclase-activating polypeptide), which is an endogenous peptide found in the placenta and uterus, is increased after stimulation of LH/ gonadotropins in ovaries. This hormone is critical for steroidogenesis, oocyte maturation and survival of granulosa cells in ovaries $(26,27)$.

As a result of this information, ADAMTS1 is a new candidate marker that indicates the competence of oocytes and the capacity of fertilization (23).

\section{Menstrual cycle and ADAMTS}

Various structural changes in the endometrial ECM are seen in the menstrual cycle. These changes are quite important for successful implantation and placental development (28). ADAMTS1, one of the considerable structures that are responsible for these changes, is effective in all uterine tissues throughout the menstrual cycle (12). ADAMTS1 has a role in matrix remodeling. The expression of ADAMTS1, which is responsible for the degradation of proteoglycans, like syndecan and perlecan, in the ECM, is increased by gonadal steroids, such as PG, estrogen, and androgens $(28,29)$. ADAMTS1, responsible for ECM remodeling, also has critical roles in the initiation and successful maintenance of decidualization (29). In ADAMTS1 knockout mice, the uterus develops, but successful implantation does not occur $(12,28)$.

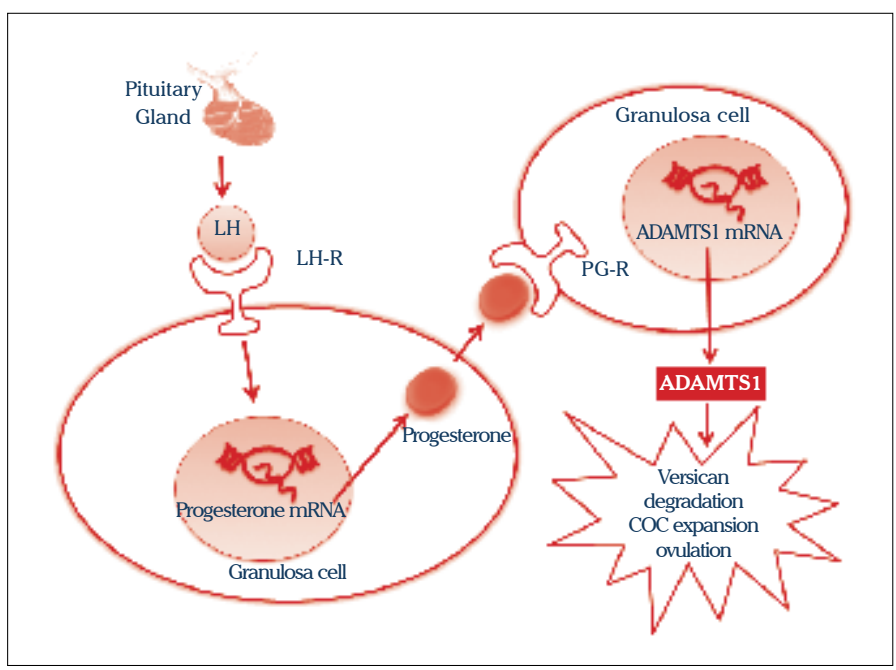

Figure 2. Luteinizing hormone (LH) secreted from the pituitary gland, increases secretion and expression of progesterone and progesterone receptor (PG-R) in granulosa cells. Progesterone leads to increased expression of ADAMTS1 by binding to its receptors (PG-R) on the granulosa cells. ADAMTS1 degrade versican. This degradation causes to expand $C O C$ formation and ovulation $(8,9,20,21)$ 


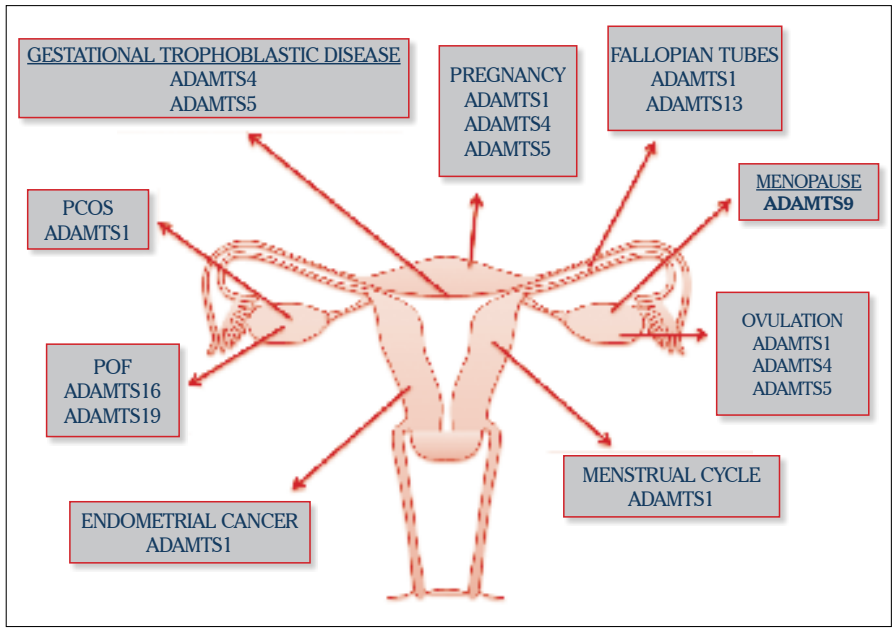

Figure 3. The role of the ADAMTS: A new biological marker candidates in physiological and pathological processes in female reproductive system

Although the expression of ADAMTS1 and -13 is increased in the fallopian tube during the menstrual cycle, there is no functional work reported in the literature (30).

\section{Pregnancy and ADAMTS}

Placenta formation for the occurrence of pregnancy is the most fundamental step. For successful placentation, the transformation cytotrophoblasts into intermediate trophoblast and the invasion of these cells into maternal tissues are needed (31). During placenta formation, extravillous trophoblasts lose their cell-cell interactions and secrete various proteases, including ADAMTS1. The functions of these cells, which invade surrounding tissues and the endometrium, are controlled very tightly. ADAMTS1 is responsible for the degradation of the ECM and the invasion of the myometrium and endometrium $(32,33)$. Interleukin 1 beta (IL-1 $\beta$ ) and transforming growth factor beta (TGF- $\beta$ ) are two cytokines that affect the expression and activity of ADAMTS1 (33). ADAMTS1 is also responsible for the formation of new blood vessels that supply the nutrients needed for the placenta and endometrium (34). In ADAMTS1 knockout mice, it was observed that the pregnancy rate declined (33). ADAMTS4 and -5 are expressed at very high levels, especially in the first-trimester placenta and are responsible for maternal tissue invasion (31).

ADAMTS5 presence in first-trimester decidual endometrial tissue was determined. IL-1 $\beta$ and TGF- $\beta 1$ are two key cytokines that affect the expression of ADAMTS5. While IL-1 $\beta$ increases the expression levels of ADAMTS5, TGF- $\beta 1$ decreases them (35). Expression of ADAMTS5 is associated with decidualization. ADAMTS5 is also thought to be responsible for the cytokine-mediated proteolytic degradation of decidual ECM (35). Gonadal steroids, like PG and dihydrotestosterone, regulate the expression of ADAMTS5, -8, and -9 in endometrium cell culture. These enzymes, which have critical roles in endometrial physiology, lead to decidualization in the endometrium. Defects in the synthesis of these proteases result in infertility (36).
In the symphysis pubis during pregnancy, several changes are seen. The expansion of the symphysis pubis is seen for the fetus to pass through the birth canal in a comfortable way. For this expansion, the synthesis of versican and HA is increased, and proteinases, like ADAMTS1, are decreased in the ECM (37). Cells obtained from amniotic fluid from pregnant women with fetuses who have neural tube defects do not make the storage of collagen. The expression of ADAMTS2 and -14 in these cells is lower (38).

In placental tissue samples taken from pregnant women in the first trimester, it was shown that ADAMTS12, independent of other metalloproteinases, was responsible for the invasion of trophoblastic cells. The expression of this protease is regulated by IL- $1 \beta$ and TGF- $\beta 1$, like ADAMTS 1 and -5 . ADAMTS 12 also regulates cell-ECM adhesion and invasion (39).

\section{Menopause and ADAMTS}

Menopause is an important physiological event closely related to women's health. Genetic studies have showed that various genes are associated with menopause. ADAMTS9 is one of these genes. The relationship between the ADAMTS9 and SMAD3 genes is associated with natural menopause age (40). Bone mineral densitometry (BMD), an examination method to determine osteoporosis, is influenced by several genetic and environmental factors. Although the peak level of BMD is influenced by diet and physical activity, genetic factors are also important. Studies about this issue showed that ADAMTS18 has been associated with femoral neck bone mineral density (41).

\section{ADAMTS in the Pathogenesis of Obstetrics and Gynecology Diseases}

Thrombotic thrombocytopenic purpura/other diseases that are predisposed to thrombosis and ADAMTS

Thrombotic thrombocytopenic purpura is a rare disease associated with thrombocyte aggregation secondary to thrombocytopenia, hemolytic anemia, and ischemic conditions. In TTP, which is an acute onset and quite fatal disease, there are hyaline thromboses in a great deal of tissue and organs (42). Although it is a rare disease, its incidence increases during pregnancy $(43,44)$. In the pathogenesis of the disease, ultralarge von Willebrand factor multimers, which must be degraded by ADAMTS13 (vWFCP) in circulation, have an essential role (42). This disease is more frequently seen in pregnancy. Pregnancyrelated hypercoagulability and decline of ADAMTS13 levels are the reasons (45). Especially in severe ADAMTS13 deficiency, TTP develops during pregnancy (46). The risk of recurrence after pregnancy is high. For this reason, early diagnosis and treatment of TTP are needed (43).

In ADAMTS13 deficiency, the incidence of HELLP, preeclampsia, and hemolytic uremic syndrome (HUS) also increases (43). In HELLP syndrome (hemolysis, elevated liver enzymes and low platelet count), active plasma vWF levels and the propeptide/ mature vWF ratio have been found to be higher than in normal pregnancy and preeclampsia. ADAMTS13 levels have been also found to be low (47). In the pathogenesis of HELLP syndrome (hemolysis, elevated liver enzymes and low platelet count), there is thought to be acute endothelial activity, like TTP (47). 
Early diagnosis and treatment of TTP in pregnancy are crucial. Measurement of ADAMTS13 levels is helpful in the diagnosis. An ADAMTS13 level of no less than 5\%, the absence of ADAMTS inhibitors, and expression of ADAMTS gene mutations will help confirm the diagnosis (48).

\section{Polycystic ovary syndrome (PCOS) and ADAMTS}

Polycystic ovary syndrome is a common disease that affects mostly women of reproductive age. In this disease, common cysts in the ovaries, oligo-anovulation, hyperandrogenism, hyperinsulinism and insulin resistance are seen. Abnormal steroidogenesis/folliculogenesis and developmental disorders in the dominant follicle result in impairment of ovarian function. The expression of ADAMTS1 is reduced in PCOS. This is thought to be associated with the failure of ovulation, impairment of oocyte quality, and declined fertilization rate (49).

\section{Premature ovarian failure (POF) and ADAMTS}

Premature ovarian failure, one of the most important diseases that cause female infertility, is a disease characterized by amenorrhea occurring before the age of 40 and hypergonadotropic hypogonadism. In the development of POF, the dysfunction and destruction of follicles are important physiological events. In genomic studies, ADAMTS19 has a role in ovarian development. It is thought ADAMTS19 may be important in the pathogenesis of POF $(50,51)$. Insulin-like growth factor (IGF2 ) increases the number of FSH receptors in granulosa cells. IGF-2 and FSH induce steroidogenesis in these cells. IGF-2 is a useful marker to identify high-risk POF patients. In the pathogenesis of POF, there is a relationship between ADAMTS19 and IGF-2 receptors (50).

Activin A is an effective hormone that provides germ cell proliferation and survival in ovaries. In the pathogenesis of POF, there is a relationship between ADAMTS19 and activin type II receptors (ACVR2) (52).

Thyroid-stimulating hormone (TSH) induces steroidogenesis induced by gonadotropin. In thyroid dysfunctions, estrogen metabolism disorders, menstrual disorders and infertility are seen. In previous studies, there was a relationship between ADAMTS16 and the TSH $\beta$ gene. This relationship is associated with POF pathogenesis (53).

\section{Gynecologic cancers and ADAMTS}

Endometrial adenocarcinoma composes $80 \%$ of endometrial cancers, which are the most frequently seen gynecologic cancers in women. In these tumors, while angiogenesis increases, invasiveness also increases. ADAMTS1 plays an important role in invasiveness associated with tumor cell migration and metastasis. Increased in endometrial adenocarcinomas, ADAMTS1 is related to epithelial cell invasion and endothelial cell function (54).

ADAMTS4 and - 5 are highly expressed in gestational trophoblastic diseases. These proteinases are closely related to the biological behavior of gestational trophoblastic disease. It is suggested that the staining pattern of these proteinases may help make the distinction between normal gestation, early complete mole, invasive mole, and choriocarcinoma (31).
Epithelial ovarian cancer composes $90 \%$ of ovarian cancers, which are the most disastrous gynecologic cancers in women. Several epigenetic changes were detected in these tumors. Methylation of DNA is one of these epigenetic mechanisms. The activity of hypermethylated genes reduces. Although HOXA9, HOXB5, CRABP1, and SCGB3A1 have been shown to be hypermethylated in ovarian carcinomas, the ADAMTS1 gene is not methylated (55).

\section{Conclusion}

We tried to point out the importance of ADAMTS proteinases, which have been hugely popular in recent years, in obstetrics and gynecology. These enzymes have very critical roles in the physiology of the female reproductive system, including ovulation and the pathogenesis of obstetric and gynecology diseases (56) (Figure 3). There are not enough studies about this subject in obstetrics and gynecology. A great deal of studies are required to analyze the ADAMTS gene promoter, discover signaling pathways and point out single-nucleotide polymorphisms (1). In these studies, the functions of this family, in the ECM context will be studied in the female reproductive system, like other tissues and organs.

Peer-review: Externally peer-reviewed.

Author contributions: Concept - K.D., I.C., S.A. E.S.; Design - K.D., I.C., S.A., E.S.; Supervision - K.D., I.C., S.A., E.S.; Resource - K.D., I.C., S.A., E.S.; Materials - K.D., I.C., S.A., E.S.; Data Collection\&/or Processing K.D., I.C., S.A., E.S., B.N.Y,; Analysis\&/or Interpretation - S.A., E.S., B.N.Y.; Literature Search - K.D., I.C., S.A.; Writing - K.D., I.C., S.A.; Critical Reviews - K.D., I.C., S.A., E.S.

Conflict of Interest: No conflict of interest was declared by the authors.

Financial Disclosure: This study has recevied financial support from TÜBİTAK.

\section{References}

1. Demircan K, Akyol S, Armutçu F. A Multi-Functional Gene Family From Arthritis to Cancer: A Disintegrin-Like Metalloproteinase with Thrombospondin Type-1 Motif (ADAMTS). J Clin Anal Med 2013; 4: 429-34. [CrossRef]

2. Gao S, De Geyter C, Kossowska K, Zhang H. FSH stimulates the expression of the ADAMTS-16 protease in mature human ovarian follicles. Mol Hum Reprod 2007; 13: 465-71. [CrossRef]

3. Wang WM, Ge G, Lim NH, Nagase H, Greenspan DS. TIMP-3 inhibits the procollagen N-proteinase ADAMTS-2. The Biochemical journal. 2006; 398: 515-9. [CrossRef]

4. Wayne GJ, Deng SJ, Amour A, Borman S, Matico R, Carter HL, et al. TIMP-3 inhibition of ADAMTS-4 (Aggrecanase-1) is modulated by interactions between aggrecan and the C-terminal domain of ADAMTS-4. Biochem J 2007; 282: 20991-8.

5. Kuno K, lizasa H, Ohno S, Matsushima K. The exon/intron organization and chromosomal mapping of the mouse ADAMTS-1 gene encoding an ADAM family protein with TSP motifs. Genomics. 1997; 46: 466-71. [CrossRef]

6. Shozu M, Minami N, Yokoyama H, Inoue M, Kurihara H, Matsushima $\mathrm{K}$, et al. ADAMTS-1 is involved in normal follicular development, ovulatory process and organization of the medullary vascular network in the ovary. J Mol Endocrinol 2005; 35: 343-55. [CrossRef] 
7. Boerboom D, Russell DL, Richards JS, Sirois J. Regulation of transcripts encoding ADAMTS-1 (a disintegrin and metalloproteinase with thrombospondin-like motifs-1) and progesterone receptor by human chorionic gonadotropin in equine preovulatory follicles. $\mathrm{J}$ Mol Endocrinol 2003; 31: 473-85. [CrossRef]

8. Espey LL, Yoshioka S, Russell DL, Robker RL, Fujii S, Richards JS. Ovarian expression of a disintegrin and metalloproteinase with thrombospondin motifs during ovulation in the gonadotropinprimed immature rat. Biol Reprod 2000; 62: 1090-5. [CrossRef]

9. Ohnishi J, Ohnishi E, Shibuya H, Takahashi T. Functions for proteinases in the ovulatory process. Biochim Biophys Acta 2005; 1751: 95-109. [CrossRef]

10. Richards JS, Hernandez-Gonzalez I, Gonzalez-Robayna I, Teuling E, Lo Y, Boerboom D, et al. Regulated expression of ADAMTS family members in follicles and cumulus oocyte complexes: evidence for specific and redundant patterns during ovulation. Biol Reprod 2005; 72: 1241-55. [CrossRef]

11. Brown HM, Dunning KR, Robker RL, Boerboom D, Pritchard M, Lane M, et al. ADAMTS1 cleavage of versican mediates essential structural remodeling of the ovarian follicle and cumulus-oocyte matrix during ovulation in mice. Biol Reprod 2010; 83: 549-57. [CrossRef]

12. Kim J, Kim H, Lee SJ, Choi YM, Lee SJ, Lee JY. Abundance of ADAM-8, -9, -10, -12, -15 and -17 and ADAMTS-1 in mouse uterus during the oestrous cycle. Reprod Fertil Dev 2005; 17: 543-55. [CrossRef]

13. Liu CJ. The role of ADAMTS-7 and ADAMTS- 12 in the pathogenesis of arthritis. Nat Clin Pract Rheumatol 2009; 5: 38-45. [CrossRef]

14. Dagoneau N, Benoist-Lasselin C, Huber C, Faivre L, Megarbane A, Alswaid A, et al. ADAMTS10 mutations in autosomal recessive Weill-Marchesani syndrome. Am J Hum Genet 2004; 75: 801-6. [CrossRef]

15. Scully M, Thomas M, Underwood M, Watson H, Langley K, Camilleri RS, et al. Thrombotic thrombocytopenic purpura and pregnancy: Presentation, management, and subsequent pregnancy outcomes. Blood 2014; 124: 211-9. [CrossRef]

16. Jia Z, Gao S, M'Rabet N, De Geyter C, Zhang H. Sp1 is necessary for gene activation of Adamts 17 by estrogen. J Cell Biochem 2014 ; 115: 1829-39. [CrossRef]

17. Somerville RP, Longpre JM, Jungers KA, Engle JM, Ro ss M, Evanko S, et al. Characterization of ADAMTS-9 and ADAMTS-20 as a distinct ADAMTS subfamily related to Caenorhabditis elegans GON-1. J Biol Chem 2003; 278: 9503-13. [CrossRef]

18. Richards JS. Ovulation: new factors that prepare the oocyte for fertilization. Mol Cell Endocrinol 2005; 234: 75-9. [CrossRef]

19. Russell DL, Doyle KM, Ochsner SA, Sandy JD, Richards JS. Processing and localization of ADAMTS- 1 and proteolytic cleavage of versican during cumulus matrix expansion and ovulation. J Biol Chem 2003; 278: 42330-9. [CrossRef]

20. Robker RL, Russell DL, Espey LL, Lydon JP, O’Malley BW, Richards JS. Progesterone-regulated genes in the ovulation process: ADAMTS-1 and cathepsin L proteases. Proc Natl Acad Sci U S A 2000; 97: 4689-94. [CrossRef]

21. Doyle KM, Russell DL, Sriraman V, Richards JS. Coordinate transcription of the ADAMTS-1 gene by luteinizing hormone and progesterone receptor. Mol Endocrinol 2004; 18: 2463-78. [CrossRef]

22. Shimada M, Nishibori M, Yamashita Y, Ito J, Mori T, Richards JS. Down-regulated expression of A disintegrin and metalloproteinase with thrombospondin-like repeats-1 by progesterone receptor antagonist is associated with impaired expansion of porcine cumulus-oocyte complexes. Endocrinology 2004; 145: 4603-14. [CrossRef]
23. Yung Y, Maman E, Konopnicki S, Cohen B, Brengauz M, Lojkin I, et al. ADAMTS-1: a new human ovulatory gene and a cumulus marker for fertilization capacity. Mol Cell Endocrinol 2010; 328: 104-8. [CrossRef]

24. Young KA, Tumlinson B, Stouffer RL. ADAMTS-1/METH-1 and TIMP3 expression in the primate corpus luteum: divergent patterns and stage-dependent regulation during the natural menstrual cycle. Mol Hum Reprod 2004; 10: 559-65. [CrossRef]

25. Barkan D, Hurgin V, Dekel N, Amsterdam A, Rubinstein M. Leptin induces ovulation in GnRH-deficient mice. FASEB J 2005; 19: 133-5.

26. Horvath G, Reglodi D, Brubel R, Halasz M, Barakonyi A, Tamas A, et al. Investigation of the Possible Functions of PACAP in Human Trophoblast Cells. J Mol Neurosci 2014; 54:320-30. [CrossRef]

27. Sayasith K, Brown KA, Sirois J. Gonadotropin-dependent regulation of bovine pituitary adenylate cyclase-activating polypeptide in ovarian follicles prior to ovulation. Reproduction 2007; 133: 441-53. [CrossRef]

28. Mishra B, Koshi K, Kizaki K, Ushizawa K, Takahashi T, Hosoe M, et al. Expression of ADAMTS1 mRNA in bovine endometrium and placenta during gestation. Domest Anim Endocrinol 2013; 45: 43-8. [CrossRef]

29. Wen J, Zhu H, Murakami S, Leung PC, MacCalman CD. Regulation of A Disintegrin And Metalloproteinase with ThromboSpondin repeats-1 expression in human endometrial stromal cells by gonadal steroids involves progestins, androgens, and estrogens. J Clin Endocrinol Metab 2006; 91: 4825-35. [CrossRef]

30. Diaz PS, Solar PA, Juica NE, Orihuela PA, Cardenas H, Christodoulides $\mathrm{M}$, et al. Differential expression of extracellular matrix components in the Fallopian tubes throughout the menstrual cycle. Reprod Biol Endocrinol 2012; 10: 56. [CrossRef]

31. Lee SY, Lee HS, Gil M, Kim CJ, Lee YH, Kim KR, et al. Differential expression patterns of a disintegrin and metalloproteinase with thrombospondin motifs (ADAMTS) $-1,-4,-5$, and -14 in human placenta and gestational trophoblastic diseases. Arch Pathol Lab Med 2014; 138: 643-50. [CrossRef]

32. Takahashi H, Yuge K, Matsubara S, Ohkuchi A, Kuwata T, Usui R, et al. Differential expression of ADAM (a disintegrin and metalloproteinase) genes between human first trimester villous and extravillous trophoblast cells. J Nippon Med Sch 2014; 81: 122-9. [CrossRef]

33. Ng YH, Zhu H, Pallen CJ, Leung PC, MacCalman CD. Differential effects of interleukin-1beta and transforming growth factorbetal on the expression of the inflammation-associated protein, ADAMTS-1, in human decidual stromal cells in vitro. Hum Reprod 2006; 21: 1990-9. [CrossRef]

34. Dunlap KA, Kwak HI, Burghardt RC, Bazer FW, Magness RR, Johnson GA, et al. The sphingosine 1-phosphate (S1P) signaling pathway is regulated during pregnancy in sheep. Biol Reprod 2010; 82: 876-87. [CrossRef]

35. Zhu H, Leung PC, MacCalman CD. Expression of ADAMTS-5/ implantin in human decidual stromal cells: regulatory effects of cytokines. Hum Reprod 2007; 22: 63-74. [CrossRef]

36. Wen J, Zhu H, Leung PC. Gonadal steroids regulate the expression of aggrecanases in human endometrial stromal cells in vitro. J Cell Mol Med 2013; 17: 1325-34. [CrossRef]

37. Rosa RG, Akgul Y, Joazeiro PP, Mahendroo M. Changes of large molecular weight hyaluronan and versican in the mouse pubic symphysis through pregnancy. Biol Reprod 2012; 86: 44. [CrossRef]

38. Hosper NA, Bank RA, van den Berg PP. Human amniotic fluidderived mesenchymal cells from fetuses with a neural tube defect do not deposit collagen type i protein after TGF-betal stimulation in vitro. Stem Cells Dev 2014; 23: 555-62. [CrossRef] 
39. Beristain AG, Zhu H, Leung PC. Regulated expression of ADAMTS-12 in human trophoblastic cells: a role for ADAMTS-12 in epithelial cell invasion? PloS One 2011; 6: e18473. [CrossRef]

40. Pyun JA, Kim S, Cho NH, Koh I, Lee JY, Shin C, Kwack K. Genomewide association studies and epistasis analyses of candidate genes related to age at menarche and age at natural menopause in a Korean population. Menopause 2014; 21: 522-9. [CrossRef]

41. Koller DL, Ichikawa S, Lai D, Padgett LR, Doheny KF, Pugh E, et al. Genome-wide association study of bone mineral density in premenopausal European-American women and replication in African-American women. J Clin Endocrinol Metab 2010; 95: 18029. [CrossRef]

42. Marques MB, Mayfield CA, Blackall DP. Thrombotic thrombocytopenic purpura: from platelet aggregates to plasma. Am J Clin Pathol 2004; (121 Suppl): S89-96.

43. Scully MA, Machin SJ. Berend Houwen Memorial Lecture: ISLH Las Vegas May 2009: the pathogenesis and management of thrombotic microangiopathies. Int J Lab Hematol 2009; 31: 268-76. [CrossRef]

44. Scully M, Starke R, Lee R, Mackie I, Machin S, Cohen H. Successful management of pregnancy in women with a history of thrombotic thrombocytopaenic purpura. Blood Coagul Fibrinolysis 2006; 17: 459-63. [CrossRef]

45. Gonzalez-Mesa E, Narbona I, Blasco M, Cohen I. Unfavorable course in pregnancy-associated thrombotic thrombocytopenic purpura necessitating a perimortem Cesarean section: A case report. J Med Case Rep 2013; 7: 119. [CrossRef]

46. Nikolaou M, Karakantza M, Adonakis G, Theodorou G, Zoumbos $\mathrm{N}$, Decavalas G. A case of severe ADAMTS13 deficiency presenting as thrombotic thrombocytopenic purpura in pregnancy. Med Pregl 2012; 65: 436-9. [CrossRef]

47. Franchini M, Montagnana M, Targher G, Lippi G. Reduced von Willebrand factor-cleaving protease levels in secondary thrombotic microangiopathies and other diseases. Semin Thromb Hemost 2007; 33: 787-97. [CrossRef]
48. Bettoni G, Palla R, Valsecchi C, Consonni D, Lotta LA, Trisolini SM, et al. ADAMTS-13 activity and autoantibodies classes and subclasses as prognostic predictors in acquired thrombotic thrombocytopenic purpura. J Thromb Haemost 2012; 10: 1556-65. [CrossRef]

49. Xiao S, Li Y, Li T, Chen M, Xu Y, Wen Y, et al. Evidence for decreased expression of ADAMTS-1 associated with impaired oocyte quality in PCOS patients. J Clin Endocrinol Metab 2014; 99: E1015-21. [CrossRef]

50. Pyun JA, Kim S, Cha DH, Kwack K. Epistasis between IGF2R and ADAMTS19 polymorphisms associates with premature ovarian failure. Hum Reprod 2013; 28: 3146-54. [CrossRef]

51. Knauff EA, Franke L, van Es MA, van den Berg LH, van der Schouw YT, Laven JS, et al. Genome-wide association study in premature ovarian failure patients suggests ADAMTS19 as a possible candidate gene. Hum Reprod 2009; 24: 2372-8. [CrossRef]

52. Pyun JA, Kim S, Kwack K. Epistasis between polymorphisms in ACVR2B and ADAMTS19 is associated with premature ovarian failure. Menopause 2014. [Epub ahead of print]

53. Pyun JA, Kim S, Cha DH, Kwack K. Epistasis between polymorphisms in TSHB and ADAMTS16 is associated with premature ovarian failure. Menopause 2014; 21: 890-5. [CrossRef]

54. Keightley MC, Sales KJ, Jabbour HN. PGF2alpha-F-prostanoid receptor signalling via ADAMTS1 modulates epithelial cell invasion and endothelial cell function in endometrial cancer. BMC Cancer 2010; 10: 488. [CrossRef]

55. Wu Q, Lothe RA, Ahlquist T, Silins I, Trope CG, Micci F, et al. DNA methylation profiling of ovarian carcinomas and their in vitro models identifies HOXA9, HOXB5, SCGB3A1, and CRABP1 as novel targets. Mol Cancer 2007; 6: 45. [CrossRef]

56. Ozler S, Demircan K. The investigation of the role of proteoglycans and ADAMTS levels in fetal membranes in physiopathological process of gestational diabetes. Med Hypotheses 2014. doi: 10.1016/j. mehy.2014.06.020. [Epub ahead of print] [CrossRef] 